\title{
The Impact of Seasonal Changes in Plant Tissue on Rhizogenesis of Stem Cuttings of the Once Flowering Roses
}

\section{Marta J. MONDER ${ }^{1 *}$, Konrad WOLIŃSKI ${ }^{1}$, Maciej NIEDZIELSKI ${ }^{1}$, Andrzej PACHOLCZAK ${ }^{2}$}

\author{
${ }^{1}$ Polish Academy of Science Botanical Garden-Centerfor Biological Diversity Conservation in Powsin, Prawdziwka 2, 02-973 Warsaw, \\ Poland;mondermarta@obpan.pl('correspondingauthor);kwolinski@obpam.pl;mniedz@obpan.pl \\ ${ }^{2}$ Warsaw University of Life Science,Department of Ornamental Plants, Nowoursynowska 159, 02-776Warsaw, Poland;pacholczak@poczta.onet.pl
}

\begin{abstract}
The majority of old and long-to-root roses are enough frost resistant to grow on their own roots in moderate and cool climates. The most often used method of rose propagation are single node stem cuttings derived from blooming shoots. The long duration of rhizogenesis exposes cuttings to stress conditions and precocious ageing processes, which result in a low rooting percentage. It was hypothesized that in the short season of flowering the amount of nutrients in shoots of stock plants changes, thus affecting the process of rhizogenesis, as well as a condition of rooted cuttings, which may be estimated by the contents of the biologically active components. The shoots of four rose cultivars were cut in four phenological stages: flower buds closed, flowers opened, just after petal shedding and 7-14 days after petal fall. The rooting percentage were counted after 10 weeks of rooting. The evaluation of plant material were carried out before and after rooting, including: soluble proteins, chlorophyll $a$ and $b$, carotenoids, polyphenolic acids, reducing and total soluble carbohydrates. The research revealed variability, characteristic for each examined cultivar, in the contents of the biologically active compounds, both before and after rooting, in cuttings harvested from stock plants in successive phases of development. Decrease in pigment contents in leaves of rooted cuttings may suggest a progressing senescence, both during propagation and later in a vegetative season. The cuttings of 'Mousseuse Rouge' rooted similarly when harvested in each of the phenological phases (53.8-67.5\%). For other cultivars the highest rooting percentage was obtained for cuttings harvested from shoots with closed flower buds: ('Hurdals' $47.5 \%$, 'Maiden's Blush' $55.0 \%$, 'Semiplena' 67.5\%). In these cultivars a relationship between rooting percentage and changes in the contents of pigments, sugars or/and polyphenolic acids in successive phenological phases was shown.
\end{abstract}

Keywords: maturity of shoots, stem cuttings, old roses, stock plant, temporal variability

\section{Introduction}

Historical roses of various origin are characterized by different flowering periods (Pihlajaniemi et al., 2005; Monder, 2007; Monder, 2014), but - both in practice and research - a date and a shoot developmental phase at the moment of cuttings' harvest is rarely considered (Monder et al., 2014; Pihlajaniemi $e t$ al., 2005). The process of rhizogenesis of historical roses by cuttings is considered to be rather long (10-12 weeks) and rooted cuttings are often of poor quality (Moroz, 2006; Monder et al., 2014; Nasri et al.,2015), especially when compared with modern roses, in which rhizogenesis lasts 4-6 weeks on the average (Costa et al., 2007; Pietrakowski, 2006; Wiśniewska-Grzeszkiewicz and Podwyszyńska, 2001). The rhizogenesis process in rose cuttings is known to be affected by many exogenous and endogenous factors, including the location in canopy (Hwnag et al., 2015), a type of cutting and a propagation date (WiśniewskaGrzeszkiewicz and Podwyszyńska, 2001; Pietrakowski, 2006).

As a consequence of the process of rhizogenesis lasting up to 10-12 weeks (Moroz, 2006; Monder et al., 2014) the single node leaf old rose cuttings are subjected to an extended period of stress conditions and precocious ageing processes. The cuttings of ground cover (Fuchs, 1986; Wiśniewska-Grzeszkiewicz and Podwyszyńska, 2001; Pietrakowski, 2006) and floribunda (Costa, 2002; Costa and Challa, 2002) roses have been rooted in 4-6 weeks. The senescence process involves an intricate and comprehensive regulation of pathways that respond to previous life stages of the leaf and various endogenous and exogenous environmental factors (Lim et al., 2007). The onset, progression and completion of these processes are regulated in a highly coordinated manner and involve an extensive reprogramming of gene expression (Woo et al., 2013). Metabolic changes during leaf senescence include the hydrolysis of macromolecules, such as 
proteins, lipids, nucleic acids and pigments that were accumulated during the growth phase (Watanabe et al., 2013). The above changes lead to death (Smart, 1994). Gitelson and Merzlyak (1994) showed, that the first process associated with leaf senescence is a decrease in chlorophyll content and increase in carotenoids (Gitelson and Merzlyak, 1994). The process of aging of cuttings is especially significant, because the leaf of the stock plant, by continuing the process of photosynthesis, is the plant's only possibility to produce chemical energy. Thus, the possibility of cuttings to continue photosynthesis during propagation should be the primary regulatory factor of survival and subsequent growth (rooting, growth of the auxiliary bud into primary shoot and dry weight accumulation) (Costa, 2002). Premature leaf senescence leads to disorders in photosynthesis, plant growth and productivity (Guan and Gan, 2014). A small part of shoot with only one node contains a limited amount of nutrients. Previous research proved that the quantity of reserves frequently restricted the plant's chances to stay alive and to continue growth especially in case of softwood and semihardwood cuttings of woody plants (Okoro and Grace, 1976). Here, the active role is played by phenolic compounds that can affect the activity of some enzymes which take part in the process of rooting (Fu et al., 2011).

Rose propagation by one-node stem cuttings is a simple method allowing to use efficiently the stock plant material. However, the studied cultivars bloom once a year, for 2-3 weeks (Monder, 2007, 2014). From the practical point of view, determining a possibility to root cuttings made from shoots in different phenological phases and choosing an optimal phase for rhizogenesis would improve efficiency of rose propagation and facilitate the work organization in a nursery.

It was hypothesized, that in successive phenological phases specific changes occur in plants which may affect rhizogenesis The objective of this study was to investigate these changes in several biologically active elements in plant material sampled from plants in different phenological phases. An evaluation of both - the effectiveness of rooting and the state of nourishment determined by measuring the contents of the biologically active elements may have a strategic quantitative and qualitative importance in the process of rhizogenesis.

\section{Materials and Methods}

\section{Biologicalmaterial}

The research were carried out in 2012-2013. The shrubs of four once flowering historical rose cultivars of different origin were growing in National Collection of Rose Cultivars of the Polish Academy of Sciences Botanical - Centre for Biological Diversity Conservation in Powsin, Poland. The following taxa were used in the study: Rosa 'Hurdals' $(R \times$ alba $\mathrm{x} R$. villosa), $R$. $\times$ alba 'Maiden's Blush', $R$. helenae 'Semiplena' (Gustavsson, 1999 ) and $R$. xcentifolia 'Mousseuse Rouge' (Rosenverzeichnis, (a)

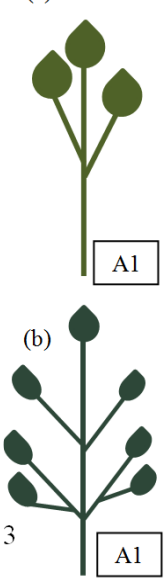

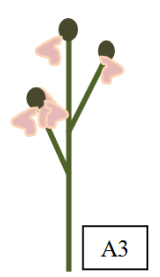
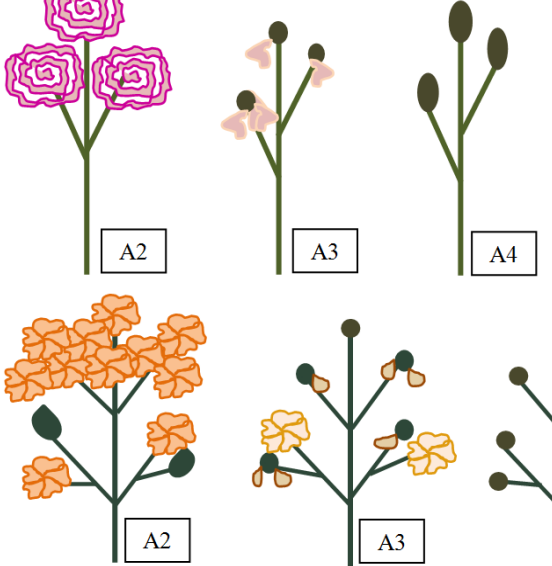

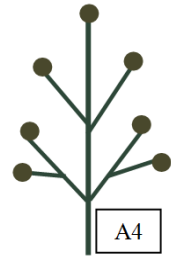

Fig. 1. The shoots of following maturity phase 'Hurdalsrose', 'Maiden's Blush', 'Mousseuse Rouge' (a) and 'Semiplena' (b). Phenological stage of shoots: A1 - flower buds closed; A2 - all flowers in an inflorescence open; A3- just after petal shedding; A4 - 7-14 days after petal fall

1988). The single node leafy stem cuttings were cut from shoots in the four following phenological phases: flower buds closed, all flowers in an inflorescence open, just after petal shedding, 7-14 days after petal fall (Fig. $1 \mathrm{a}$ and $\mathrm{b}$ ). The dates of harvesting the plant material were different for cultivars and are presented in Table 1 . The cuttings were planted in multipot trays $(6.6 \times 6.6$ $\mathrm{cm}$ ), in the peat substrate ( $\mathrm{pH}$ 6-6.5), without using preparations supporting rhizogenesis, and rooted in standard conditions in a foil tunnel $\left(23-25^{\circ} \mathrm{C}\right)$, ambient relative humidity $\left.80-90 \%\right)$ in the commercial nursery of M. M. Kryt in Wola Prażmowska $\left(51.56^{\circ} \mathrm{N}, 20.28^{\circ} \mathrm{E}\right)$. The cuttings were dug after 10 weeks of rooting and the rooting percentage was counted.

\section{Analysis of plantmaterial}

The samples for biochemical analysis were frozen and kept under $-18{ }^{\circ} \mathrm{C}$ until analyses. which were carried out in the Department of the Evaluation and Plant Biodiversity Conservation of the Polish Academy of Science Botanical Garden - Center for Biological Diversity Conservation in Powsin (pigments and proteins) and in the Department of Ornamental Plants of Warsaw University of Life Science (carbohydrates and polyphenolic acids).

Chlorophyll $a, b$ and carotenoids. The leaves were sampled thrice: on the day of harvesting cuttings from shoots in four maturity phase of stock plants, while the second time, the leaves of cuttings were sampled in August after the rooting period. To evaluate changes in the contents of the photosynthetic pigments during the whole period of vegetation, in August we collected leaves from analogical shoots with flowers past their full bloom

Table 1 . The dates of harvesting the rose shoots

\begin{tabular}{lcccc}
\hline & & \multicolumn{2}{c}{ Phenological stage of shoots } \\
\cline { 3 - 4 } Cultivar & $\begin{array}{c}\text { The average of leaf area } \\
\text { of cutting }\left[\mathrm{cm}^{2}\right]\end{array}$ & $\begin{array}{c}\text { Flower buds } \\
\text { closed }\end{array}$ & $\begin{array}{c}\text { All flowers in an } \\
\text { inflorescence open }\end{array}$ & $\begin{array}{c}\text { Just after } \\
\text { petal shedding }\end{array}$ \\
\cline { 3 - 5 } & $24-27$ & A1 & A2 & A3 \\
'Hurdalsrose' & $24-27$ & 27 May & 1 June & 6 June \\
'Maiden's Blush' & $21-25$ & 1 June & 9 June & 17 June \\
'Mousseuse Rouge' & $15-20$ & 29 May & 8 June & 28 June \\
'Semiplena' & 7 June & 12 June & 2 July & 20 June \\
\hline
\end{tabular}


94

from stock plants in the collection. Pigments were extracted with 99\% acetone. The contents of pigments were measured spectrophotometrically. The absorbance was measured at a wave length of 750, 662, 645 and $470 \mathrm{~nm}$ (GeneQuant 1300, GE) and the results have been calculated according to Arnon (1949).

Proteins. The material for analysis were leaves of stock plants sampled in June and August, as well as these taken from the cuttings after rooting. The total content of soluble proteins in the leaves was determined in supernatant obtained in extraction buffer (0.063 M TRIS, 2\% SDS, 5\% $\beta$-mercaptoethanol, 10\% glycerol). The concentration of protein was assessed according to the modified method of Ghosh et al. (1988). The eluate absorption was measured at the wave length of $590 \mathrm{~nm}$ (spectrophotometer Gene Quant 1300, GE). The total content of soluble proteins was estimated on the basis of the standard curve for BSA solutions.

The same protein extracts were used for the qualitative estimation of the electrophoretic profile, with the use of the Laemmlie SDS-PAGE discontinuous system (Moberg et al., 1987). Electrophoretic separation of proteins in leaves were conducted before rooting. Samples of protein extract were placed on a polyacrylamide gel and separated vertically (Hoefer SE 600), with the amperage of $30 \mathrm{~mA}$ in the stacking gel (T 3\%) and 45 $\mathrm{mA}$ in the separating gel (T 10\%). We performed the analysis from transition of the trace dye front (bromophenol blue) at a distance of approximately $1 \mathrm{~cm}$ from the bottom verge of the gel. After taking out from the apparatus, the gels were stained in the solution of Coomasie Brilliant Blue (CBB) R-250 (0.25\%) in methanol (40\%) and acetic acid (10\%). The gels were de-stained until the colour background vanished. After drying the sample the effects were studied visually.

Polyphenolic acids. The material was a mixture of leaves and shoots of cuttings before and after rooting. The content of dry mass in the plant material was estimated according to the method of Strzelecka et al. (1982). Polyphenolic acids were measured by the colorimetric method with the Arnow's reagent according to the Polish Norm PN-91/R-87019 (PTF, 1999). A Shimadzu UV-1601 PC spectrophotometer was used in the tests and the material was subjected to measurements of absorbance at the wave length of $490 \mathrm{~nm}$ in relation to the reference sample test. The content of polyphenolic acids was calculated into caffeic acid.

Carbohydrates. The content of carbohydrates was estimated separately in leaves and shoots, for each of the studied phases of shoot maturity, twice: before and after rooting. In order to determine the content of reducing sugars the Somogyi colorimetric method with Nelson's modification (1944) was used. The measurements were made with UV-1601 PC (Shimadzu) spectrophotometer with the wave length of $250 \mathrm{~nm}$ in relation to the reference sample test. The content of reducing sugars was read from the calibration curve for glucose. The content of total soluble sugars was determined according to the method of Dubois et al. (1956) by the wave length of $490 \mathrm{~nm}$ in relation to the reference sample test. The contents of total sugars were calculated on the basis of a standard containing $3 \mathrm{ml}$ of glucose in $100 \mathrm{ml}$. The results were calculated for one gram of dry mass and presented in $\mathrm{mg}^{\circ} \mathrm{C}_{6} \mathrm{H}_{12} \mathrm{O}_{6} \mathrm{~g} \mathrm{DW}^{-1}$.

\section{Dataanalysis}

The material for analysis from stock plants before rooting was taken randomly from 300-400 cuttings. For each phase of shoot maturity 20 cuttings were rooted in four repetitions, which makes a total of 320 cuttings for each cultivar. The content of the active biologically compounds were determined for six repetitions. The all results were subjected to the ANOVA procedure using STATISTICA 10 software (Statsoft Polska, Kraków). The Duncan's (the content of biologically active components) and Tukey's (rooting percentage) tests were used. The correlation between rooting percentage and content of biologically active components before rooting in relation to phenological phases of shoots were calculated. The values in percentage has been transformed using the function $\operatorname{ARCSIN~}(\mathrm{x})^{1 / 2}$ according to Bliss (Wójcik and Laudański, 1989).

\section{Results}

\section{Qualitative and quantitative changes in plant material}

Pigments. The content of chlorophyll $a$ and $b$ and carotenoids in stock plant leaves in each phase of maturity

Table 2. The content of chlorophyll $a(\mathrm{a}), b(\mathrm{~b})$ and carotenoids $(\mathrm{c})\left(\mathrm{mg} \cdot \mathrm{g}^{-1} \mathrm{FW}\right)$ in leaves of roses before rooting, mother plants in August and in rooted cuttings

\begin{tabular}{|c|c|c|c|c|c|c|c|c|c|c|c|c|c|}
\hline \multirow[b]{3}{*}{ 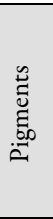 } & \multirow[b]{3}{*}{ Stage } & \multicolumn{12}{|c|}{ Cultivar } \\
\hline & & \multicolumn{3}{|c|}{ 'Hurdals' } & \multicolumn{3}{|c|}{ 'Maiden's Blush' } & \multicolumn{3}{|c|}{ 'Mousseuse Rouge' } & \multicolumn{3}{|c|}{ 'Semiplena' } \\
\hline & & $\begin{array}{l}\text { Before } \\
\text { rooting } \\
\text { in June }\end{array}$ & $\begin{array}{l}\text { Mother } \\
\text { plants } \\
\text { in } \\
\text { August }\end{array}$ & $\begin{array}{l}\text { Rooted } \\
\text { cuttings } \\
\text { in } \\
\text { August }\end{array}$ & $\begin{array}{l}\text { Before } \\
\text { rooting } \\
\text { in June }\end{array}$ & $\begin{array}{l}\text { Mother } \\
\text { plants } \\
\text { in } \\
\text { August }\end{array}$ & $\begin{array}{c}\text { Rooted } \\
\text { cuttings } \\
\text { in } \\
\text { August }\end{array}$ & $\begin{array}{l}\text { Before } \\
\text { rooting } \\
\text { in June }\end{array}$ & $\begin{array}{l}\text { Mother } \\
\text { plants } \\
\text { in } \\
\text { August }\end{array}$ & $\begin{array}{l}\text { Rooted } \\
\text { cuttings } \\
\text { in } \\
\text { August }\end{array}$ & $\begin{array}{l}\text { Before } \\
\text { rooting } \\
\text { in June }\end{array}$ & $\begin{array}{l}\text { Mother } \\
\text { plants } \\
\text { in } \\
\text { August }\end{array}$ & $\begin{array}{c}\text { Rooted } \\
\text { cuttings } \\
\text { in } \\
\text { August }\end{array}$ \\
\hline \multirow{4}{*}{ 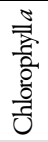 } & $\mathrm{A}^{*}{ }^{*}$ & $0.59 c^{* *}$ & $0.88 \mathrm{~d}$ & $0.39 \mathrm{~d}$ & $0.74 \mathrm{~b}$ & $0.58 \mathrm{c}$ & $0.43 \mathrm{e}$ & $0.75 \mathrm{c}$ & $0.85 \mathrm{~b}$ & $0.46 \mathrm{~d}$ & $0.56 \mathrm{~b}$ & $0.41 \mathrm{~d}$ & $0.40 \mathrm{~d}$ \\
\hline & $\mathrm{A} 2$ & $1.24 \mathrm{c}$ & $0.88 \mathrm{~d}$ & $0.53 \mathrm{c}$ & $0.82 \mathrm{ab}$ & $0.58 \mathrm{c}$ & $0.48 \mathrm{de}$ & $0.74 \mathrm{c}$ & $0.85 \mathrm{~b}$ & $0.46 \mathrm{~d}$ & $0.46 c$ & $0.41 \mathrm{~d}$ & $0.26 \mathrm{f}$ \\
\hline & A3 & $1.26 \mathrm{c}$ & $0.88 \mathrm{~d}$ & $0.38 \mathrm{~d}$ & $0.80 \mathrm{ab}$ & $0.58 \mathrm{c}$ & $0.48 \mathrm{de}$ & $0.95 \mathrm{a}$ & $0.85 \mathrm{~b}$ & $0.39 \mathrm{e}$ & $0.42 \mathrm{~cd}$ & $0.41 \mathrm{~d}$ & $0.34 \mathrm{e}$ \\
\hline & A4 & $1.26 \mathrm{c}$ & $0.88 \mathrm{~d}$ & no rooted & $0.86 \mathrm{a}$ & $0.58 \mathrm{c}$ & $0.54 \mathrm{~cd}$ & $0.73 \mathrm{c}$ & $0.85 \mathrm{~b}$ & $0.34 \mathrm{e}$ & $0.76 \mathrm{a}$ & $0.41 \mathrm{~d}$ & $0.22 \mathrm{~g}$ \\
\hline \multirow{4}{*}{$\begin{array}{l}\frac{0}{3} \\
\frac{1}{0} \\
\frac{0}{0} \\
\frac{0}{0}\end{array}$} & Al & $0.27 \mathrm{c}$ & $0.39 \mathrm{~d}$ & $0.16 \mathrm{~d}$ & $0.34 \mathrm{~b}$ & $0.24 \mathrm{c}$ & $0.17 \mathrm{~d}$ & $0.31 \mathrm{~d}$ & $0.40 \mathrm{e}$ & $0.20 \mathrm{~d}$ & $0.25 \mathrm{~b}$ & $0.17 \mathrm{~cd}$ & $0.17 \mathrm{~d}$ \\
\hline & A2 & $0.54 \mathrm{a}$ & $0.39 \mathrm{~d}$ & $0.23 \mathrm{c}$ & $0.38 \mathrm{a}$ & $0.24 \mathrm{c}$ & $0.19 \mathrm{~d}$ & $0.29 \mathrm{~b}$ & $0.40 \mathrm{e}$ & $0.21 \mathrm{~d}$ & $0.20 \mathrm{c}$ & $0.17 \mathrm{~cd}$ & $0.11 \mathrm{f}$ \\
\hline & A3 & $0.57 \mathrm{a}$ & $0.39 \mathrm{~d}$ & $0.16 \mathrm{~d}$ & $0.38 \mathrm{a}$ & $0.24 \mathrm{c}$ & $0.18 \mathrm{~d}$ & $0.44 \mathrm{a}$ & $0.40 \mathrm{e}$ & $0.14 \mathrm{e}$ & $0.20 c$ & $0.17 \mathrm{~cd}$ & $0.15 \mathrm{e}$ \\
\hline & A4 & $0.57 \mathrm{a}$ & $0.39 \mathrm{~d}$ & no rooted & $0.40 \mathrm{a}$ & $0.24 \mathrm{c}$ & $0.23 c$ & $0.33 \mathrm{~cd}$ & $0.40 \mathrm{e}$ & $0.33 \mathrm{~b}$ & $0.35 \mathrm{a}$ & $0.17 \mathrm{~cd}$ & $0.08 \mathrm{~g}$ \\
\hline \multirow{4}{*}{ 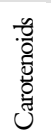 } & Al & $0.63 \mathrm{c}$ & $0.90 \mathrm{~b}$ & $0.31 \mathrm{e}$ & $0.80 \mathrm{~b}$ & $0.55 \mathrm{c}$ & $0.37 \mathrm{~d}$ & $0.70 \mathrm{c}$ & $0.83 \mathrm{~b}$ & $0.42 \mathrm{~d}$ & $0.60 \mathrm{~b}$ & $0.40 \mathrm{c}$ & $0.36 \mathrm{de}$ \\
\hline & $\mathrm{A} 2$ & $1.21 \mathrm{a}$ & $0.90 \mathrm{~b}$ & $0.44 \mathrm{~d}$ & $0.86 \mathrm{ab}$ & $0.55 \mathrm{c}$ & $0.38 \mathrm{~d}$ & $0.71 \mathrm{c}$ & $0.83 \mathrm{~b}$ & $0.43 \mathrm{~d}$ & $0.45 c$ & $0.40 \mathrm{c}$ & $0.21 \mathrm{a}$ \\
\hline & A3 & $1.27 \mathrm{a}$ & $0.90 \mathrm{~b}$ & $0.32 \mathrm{e}$ & $0.87 \mathrm{ab}$ & $0.55 \mathrm{c}$ & $0.39 \mathrm{~d}$ & $0.96 \mathrm{a}$ & $0.83 \mathrm{~b}$ & $0.31 \mathrm{e}$ & $0.46 c$ & $0.40 \mathrm{c}$ & $0.32 \mathrm{~d}$ \\
\hline & A4 & $1.27 \mathrm{a}$ & $0.90 \mathrm{~b}$ & no rooted & $0.92 \mathrm{a}$ & $0.55 \mathrm{c}$ & $0.49 c$ & $0.67 \mathrm{c}$ & $0.83 \mathrm{~b}$ & $0.34 \mathrm{e}$ & $0.80 \mathrm{a}$ & $0.40 \mathrm{c}$ & $0.12 \mathrm{f}$ \\
\hline
\end{tabular}

${ }^{*}$ Note: Maturity phase: A1 - flower buds closed; A2 - opened flowers; A3 - just after petal shedding; A $4-7-14$ after falling petals.
${ }^{* *}$ Note: Different letters indicate significant interactions between maturity phase and origin of leaves, according to Duncan's test ( $\alpha=0.05$, two-factorial ANOVA). 
Table 3. The content of polyphenolic acids

\begin{tabular}{lccccccccc}
\hline \multirow{2}{*}{ Stage } & \multicolumn{2}{c}{ 'Hurdals' } & \multicolumn{2}{c}{$\begin{array}{c}\text { 'Maiden's } \\
\text { Blush' }\end{array}$} & \multicolumn{2}{c}{$\begin{array}{c}\text { 'Mousseuse } \\
\text { Rouge' }\end{array}$} & \multicolumn{2}{c}{ 'Semiplena' } \\
\cline { 2 - 10 } & $\begin{array}{c}\text { Before } \\
\text { rooting }\end{array}$ & $\begin{array}{c}\text { After } \\
\text { rooting }\end{array}$ & $\begin{array}{c}\text { Before } \\
\text { rooting }\end{array}$ & $\begin{array}{c}\text { After } \\
\text { rooting }\end{array}$ & $\begin{array}{c}\text { Before } \\
\text { rooting }\end{array}$ & $\begin{array}{c}\text { After } \\
\text { rooting }\end{array}$ & $\begin{array}{c}\text { Before } \\
\text { rooting }\end{array}$ & $\begin{array}{c}\text { After } \\
\text { rooting }\end{array}$ \\
\hline $\mathrm{A}^{*}$ & $8.3 \mathrm{c}^{* *}$ & $8.0 \mathrm{~d}$ & $17.5 \mathrm{a}$ & $9.7 \mathrm{f}$ & $7.7 \mathrm{c}$ & $7.1 \mathrm{~d}$ & $11.6 \mathrm{~b}$ & $10.4 \mathrm{c}$ \\
$\mathrm{A} 2$ & $7.6 \mathrm{e}$ & $10.1 \mathrm{a}$ & $15.5 \mathrm{~b}$ & $10.3 \mathrm{e}$ & $8.2 \mathrm{~b}$ & $7.4 \mathrm{c}$ & $10.6 \mathrm{c}$ & $10.1 \mathrm{~d}$ \\
$\mathrm{~A} 3$ & $7.7 \mathrm{e}$ & $9.6 \mathrm{~b}$ & $12.8 \mathrm{~d}$ & $7.6 \mathrm{~h}$ & $8.1 \mathrm{~b}$ & $6.9 \mathrm{~d}$ & $12.1 \mathrm{a}$ & $10.1 \mathrm{~d}$ \\
$\mathrm{~A} 4$ & $7.3 \mathrm{f}$ & $\begin{array}{c}\text { not } \\
\text { rooted }\end{array}$ & $13.1 \mathrm{c}$ & $9.0 \mathrm{~g}$ & $7.9 \mathrm{bc}$ & $9.0 \mathrm{a}$ & $12.0 \mathrm{a}$ & $9.1 \mathrm{e}$ \\
\hline
\end{tabular}

*Note: Phenological stage of shoots: A1 - flower buds closed; A2 - all flowers in an inflorescence open; A3- just after petal shedding; A4 - 7-14 days after petal fall.

${ }^{* *}$ Note: Different letters indicate significant interactions between content of polyphenolic acids before and after rooting in all phenological phases, according to Duncan's test ( $\alpha=0.05$, two-factorial ANOVA).

depended on the cultivar. Before rooting the pigments content in leaves of 'Hurdals' cuttings taken from shoots with opened flowers, just after petal fall and 7-14 days after petal shedding reached values even several dozens higher than in other cultivars. In 'Hurdals', 'Maiden's Blush' and 'Semiplena', before rooting, a tendency to increase in the content of pigments towards the next phenological phase was observed. In the leaves of stock plants growing in collection and cut in August in 'Hurdals', 'Maiden's Blush' and 'Semiplena' the content of pigments before rooting decreased in relation to their content in leaves of shoots cut on the last date. For chlorophyll in 'Hurdals' the decrease was 29.1\%, in 'Maiden's Blush' 32.6\% and in 'Semiplena' 46.1\%. Only in leaves of 'Mousseuse Rouge' the content of pigments in August was higher than in June - 14.2\% for chlorophyll a (Table 2).

During the process of rhizogenesis the content of pigments in the leaves of cuttings decreased in relation to the state before rooting and it was also lower than in the case of stock plants at the same period (August), with chlorophyll $a$ at the level of 0.22$0.54 \mathrm{mgg}^{-1} \mathrm{FW}$. It was observed that the levels of chlorophyll $a$ and $b$ and carotenoids in a given cultivar were proportional in each individual phase and they likewise proportionally decreased during the rhizogenesis process. In 'Hurdals' the content of chlorophyll $a$ after rooting was $66.1 \%$ of the level before rooting for $\mathrm{Al}$ (for the stage description refer to Figure 1), $42.7 \%$ for $\mathrm{A} 2$ and $30.1 \%$ for $\mathrm{A} 3$ and these values were significantly lower than the ones obtained in the stock plants in August. In 'Maiden's Blush' the decrease of the pigment content in leaves was less apparent, and for stage A4 the content of all pigments was similar to the one in stock plant leaves in the same period. In 'Semiplena' A1 cuttings the level of pigments was similar to this in stock plant leaves in the same period, and for A2-A4 cuttings - it was lower. In 'Mousseuse Rouge' the content of chlorophyll $a$ and carotenoids dropped with each phase of maturity (Table 2).

Proteins. The total content of soluble proteins in each shoot phenological phase varied depending on the cultivar and after rooting it was lower ('Maiden's Blush', 'Semiplena'), higher than ('Mousseuse Rouge') or similar to ('Hurdals') the one in the stock plants in August. No clear tendency, however, was observed in the direction of changes in the content of this element in leaves before and after rhizogenesis in relation to the shoot maturity phase. In stock plant leaves taken in August the total content of protein in 'Hurdals' and 'Mousseuse Rouge' was lower, in 'Maiden's Blush' it was higher and in 'Semiplena' similar for A1, A3 and A4 in relation to the content in June (Fig. 2). As far as the electrophoretic pattern is regarded, no evident changes were observed, which may lead to a conclusions that no or very small qualitative changes occurred (Fig. 3).

Polyphenolic acids. The content of polyphenolic acids in the plant material taken from the stock plants before rooting had a different pattern in shoot maturity phases for each cultivar. In 'Hurdals' and 'Maiden's Blush' the material taken in stage Al contained the biggest amount of the studied acids. In 'Mousseuse Rouge' the highest content of polyphenolic acids occurred in the plant material coming from shoots of stages $\mathrm{A} 2$ and $\mathrm{A} 3$, and in 'Semiplena' - from A3 and A4.

After rooting of the cuttings in all phases of 'Maiden's Blush' and 'Semiplena', A1, A2 and A3 of 'Moussuse Rouge' and A1 of 'Hurdals' the polyphenolic acid contents tended to decrease in relation to that before rooting. Changes towards an increase after rooting were seen only in 'Hurdals' for A2 and A3 and in 'Mousseuse Rouge' - for A4 (Table 3).

Carbohydrates in leaves. Before rooting the contents of reducing and the total soluble sugars in leaves of 'Hurdals', 'Mousseuse Rouge' and 'Semiplena' grew with each consecutive phase of shoot maturity. In 'Maiden's Blush' the increase

Table 4. The content of reducing and total soluble carbohydrates in leaves and shoots

\begin{tabular}{|c|c|c|c|c|c|c|c|c|c|}
\hline \multirow[t]{2}{*}{ Cultivar } & \multirow[t]{2}{*}{ Stage } & \multicolumn{2}{|c|}{$\begin{array}{c}\text { Reducing carbohydrates } \\
\text { in leaves }\end{array}$} & \multicolumn{2}{|c|}{$\begin{array}{c}\text { Total soluble carbohydrates } \\
\text { in leaves }\end{array}$} & \multicolumn{2}{|c|}{$\begin{array}{c}\text { Reducing carbohydrates } \\
\text { in shoots }\end{array}$} & \multicolumn{2}{|c|}{$\begin{array}{c}\text { Total soluble carbohydrates } \\
\text { in shoots }\end{array}$} \\
\hline & & Before rooting & After rooting & Before rooting & After rooting & Before rooting & After rooting & Before rooting & After rooting \\
\hline \multirow{4}{*}{ 'Hurdals' } & $\mathrm{A} 1^{*}$ & $53.6 \mathrm{f}^{* *}$ & $69.1 \mathrm{e}$ & $74.5 \mathrm{~g}$ & $80.9 \mathrm{f}$ & $39.2 \mathrm{f}$ & $43.4 \mathrm{e}$ & $60.2 \mathrm{c}$ & $74.7 \mathrm{a}$ \\
\hline & $\mathrm{A} 2$ & $82.0 \mathrm{c}$ & $79.2 \mathrm{~d}$ & $106.9 \mathrm{~d}$ & $95.8 \mathrm{e}$ & $61.1 \mathrm{a}$ & $60.4 \mathrm{a}$ & $69.7 \mathrm{~b}$ & $69.9 \mathrm{~b}$ \\
\hline & $\mathrm{A} 3$ & $93.6 \mathrm{~b}$ & $82.6 \mathrm{c}$ & $118.1 \mathrm{c}$ & $139.1 \mathrm{a}$ & $50.0 \mathrm{c}$ & $47.2 \mathrm{~d}$ & $73.3 \mathrm{a}$ & $56.8 \mathrm{~d}$ \\
\hline & A4 & $100.4 \mathrm{a}$ & - & $129.2 \mathrm{~b}$ & - & $56.8 \mathrm{~b}$ & - & $69.9 \mathrm{~b}$ & - \\
\hline \multirow{4}{*}{ 'Maiden's Blush' } & $\mathrm{A} 1$ & $133.8 \mathrm{f}$ & $157.1 \mathrm{c}$ & $215.2 b$ & $177.4 \mathrm{c}$ & $58.5 \mathrm{c}$ & $47.8 \mathrm{e}$ & $113.1 \mathrm{~b}$ & $103.9 \mathrm{c}$ \\
\hline & A2 & $152.2 \mathrm{~d}$ & $189.8 \mathrm{a}$ & $212.7 b$ & $226.6 \mathrm{a}$ & $56.1 \mathrm{~cd}$ & $81.7 b$ & $101.4 \mathrm{c}$ & $108.7 \mathrm{bc}$ \\
\hline & A3 & $123.4 \mathrm{~g}$ & $140.0 \mathrm{e}$ & $173.7 \mathrm{c}$ & $208.5 b$ & $56.9 \mathrm{~cd}$ & $85.5 \mathrm{a}$ & $111.8 \mathrm{bc}$ & $136.2 \mathrm{a}$ \\
\hline & A4 & $123.3 \mathrm{~g}$ & $162.2 \mathrm{~b}$ & $137.7 \mathrm{~d}$ & $178.7 \mathrm{c}$ & $43.4 \mathrm{f}$ & $55.2 \mathrm{~d}$ & $85.7 \mathrm{~d}$ & $113.1 \mathrm{~b}$ \\
\hline \multirow{4}{*}{ 'Mousseuse Rouge' } & A1 & $81.7 \mathrm{e}$ & $57.8 \mathrm{f}$ & $99.7 \mathrm{f}$ & $103.5 \mathrm{f}$ & $46.2 \mathrm{f}$ & $41.5 \mathrm{~g}$ & $51.9 \mathrm{e}$ & $48.1 \mathrm{f}$ \\
\hline & $\mathrm{A} 2$ & $108.0 \mathrm{c}$ & $128.5 \mathrm{a}$ & $134.8 \mathrm{e}$ & $145.3 \mathrm{~cd}$ & $64.9 \mathrm{a}$ & $56.5 \mathrm{~b}$ & $74.3 \mathrm{~d}$ & $92.1 \mathrm{a}$ \\
\hline & A3 & $104.7 \mathrm{~cd}$ & $103.0 \mathrm{~d}$ & $148.4 \mathrm{c}$ & $157.8 \mathrm{~b}$ & $51.8 \mathrm{~d}$ & $57.9 \mathrm{~b}$ & $79.2 \mathrm{c}$ & $87.5 \mathrm{~b}$ \\
\hline & A4 & $118.9 \mathrm{~b}$ & $131.4 \mathrm{a}$ & $165.8 \mathrm{a}$ & $142.5 \mathrm{~b}$ & $49.1 \mathrm{e}$ & $54.5 \mathrm{c}$ & $89.9 \mathrm{ab}$ & $91.7 \mathrm{a}$ \\
\hline \multirow{4}{*}{ 'Semiplena' } & A1 & $47.7 \mathrm{~h}$ & $63.5 \mathrm{~d}$ & $65.9 \mathrm{e}$ & $67.1 \mathrm{e}$ & $27.1 \mathrm{e}$ & $42.6 c$ & $64.0 \mathrm{e}$ & $59.7 \mathrm{f}$ \\
\hline & $\mathrm{A} 2$ & $55.1 \mathrm{~g}$ & $66.7 \mathrm{e}$ & $84.8 \mathrm{~d}$ & $95.0 \mathrm{c}$ & $37.3 \mathrm{~d}$ & $40.3 \mathrm{~cd}$ & $64.4 \mathrm{e}$ & $91.0 \mathrm{~b}$ \\
\hline & A3 & $92.0 \mathrm{~d}$ & $111.3 \mathrm{a}$ & $112.4 b$ & $115.6 \mathrm{~b}$ & $46.7 \mathrm{c}$ & $48.1 \mathrm{~b}$ & $92.2 \mathrm{~b}$ & $123.7 \mathrm{a}$ \\
\hline & A4 & $99.8 \mathrm{c}$ & $105.6 \mathrm{~b}$ & $114.9 \mathrm{~b}$ & $150.7 \mathrm{a}$ & $39.2 \mathrm{~d}$ & $70.5 \mathrm{a}$ & $78.7 \mathrm{~d}$ & $85.4 \mathrm{c}$ \\
\hline
\end{tabular}

"Note: Phenological stage of shoots: A1 - flower buds closed; A2 - all flowers in an inflorescence open; A3- just after petal shedding; A4 - 7-14 days after petal fall.

${ }^{*}$ Note: Different lettersindicate significant interactions between content of sugars before and after rooting in all phenological phases, according to Duncan'stest $(\alpha=0.05$, two-factorial ANOVA). 
96
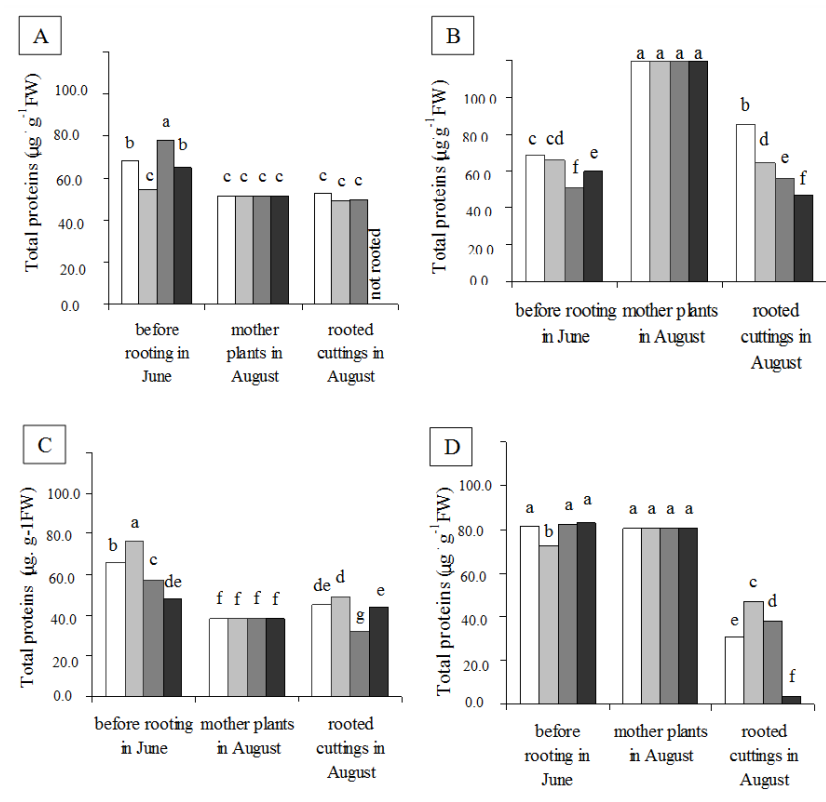

Fig. 2. The content of soluble proteins $\left(\mu \mathrm{g} \cdot \mathrm{g}^{-1} \mathrm{FW}\right)$ in leaves Rosa 'Hurdals' (A), 'Maiden's Blush' (B), 'Mousseuse Rouge' (C) and 'Semiplena' (D) before rooting, of mother plants in August and in rooted cuttings. Maturity phase: A1 - flower buds closed; A2 - opened flowers; A3 - just after falling petals; A4 - 7-14 after falling petals. Different letters indicate significant interactions between maturity phase and origin of leaves, according to Duncan's test $(\alpha=0.05$, two-factorial ANOVA)

progressed until full bloom and then the content of sugars dropped. After rooting 'Hurdals' and 'Semiplena' had a clear increasing tendency in all consecutive phases. In 'Maiden's Blush' the reducing sugars increased in all stages, while the contents of total soluble carbohydrates increased in A2-A4 stages and decreased significantly in stage A1. In 'Mousseuse Rouge' the content of reducing sugars dropped in A1 and the total in A4 (Table 4).

Carbohydrates in shoots. In the case of 'Hurdals', for shoots of phase A1 the contents of reducing sugars and the total soluble sugars in shoots were higher after the rooting than before it, for A2 shoots it was similar and for A3 ones it was lower. In 'Maiden's Blush' before rooting the contents of reducing sugars and the total soluble sugars dropped with each consecutive phase of shoot maturity. After rooting the highest average values were obtained for A3. In the case of 'Mousseuse Rouge' before rooting the content of reducing sugars and total sugars were the lowest in A1 shoots. In the shoots of rooted cuttings of phase Al the content of reducing and total sugars decreased to the lowest level for this cultivar. In phase A2 the content of reducing sugars decreased and the total sugars increased. In the next two phases the increasing tendency continued. In 'Semiplena' before rooting the content of reducing sugars and the total sugars increased with A1-A3, then dropped. After rooting the content of reducing carbohydrates increased in shoots of all phases. The total sugars decreased for $\mathrm{A} 1$ and increased for remaining phases in relation to before rooting.

Moreover, the difference between the content of reducing and total soluble sugars was high The differences before rooting
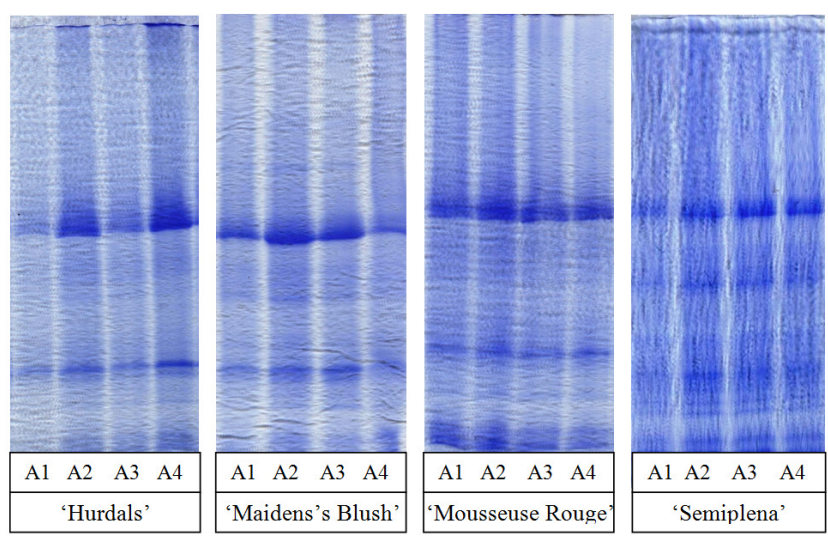

Fig. 3. Electrophoretic patterns of proteins from leaves on SDS-PAGE gel - samples of proteins extracted from leaves before rooting. Maturity phase of shoots: A1 - flower buds closed; A2 - opened flowers; A3 - just after petal shedding; A4 -7-14 after falling petals

in consecutive phases it reached for example in 'Semiplena', respectively: $6.9 \%, 27.1 \%, 45.5 \%$ and $39.5 \%$. After rooting these differences were respectively: $17.1 \%, 50.7 \%, 75.6 \%, 14.9 \%$ (Table 4).

\section{The condition of stock plants in relation to rhizogenesis}

The research showed that the phenological phase of shoots had a dominant influence the rhizogenesis of cuttings of the studied rose cultivars, 'Mousseuse Rouge' being the exception. The cuttings of 'Hurdals' cut from shoots 7-14 days after falling petals did not root. The results of rooting percentage are presented in Table 5 . The analysis showed correlations between the percent of the rooted cuttings and the content of biologically active components in mother plants for three of the four studied cultivars: 'Hurdals', 'Maiden's Blush' and 'Semiplena'. In 'Hurdals' and 'Maiden's Blush' an increased content of polyphenolic acids correlated with a high rooting percentage. The lower content of pigments in leaves of 'Maiden's Blush' and 'Semiplena' was related to a higher percentage of rooted cuttings. The content of carbohydrates, in turn, both in leaves and in shoots of stock plants was related to the positive results of rhizogenesis of 'Hurdals' (a lowered one) and 'Maiden's Blush' (an increased one) (Table 6).

\section{Discussion}

The present study on once-flowering and difficult-toroot roses showed the changes of basic biologically active elements in plant material by a fluent consecution of

Table 5. The rooting percentage of roses

\begin{tabular}{lcccc}
\hline & \multicolumn{4}{c}{ Phenological stage of shoots } \\
\cline { 2 - 5 } Cultivar & $\begin{array}{c}\text { Flower } \\
\text { buds closed }\end{array}$ & $\begin{array}{c}\text { All flowers } \\
\text { open }\end{array}$ & $\begin{array}{c}\text { Just after } \\
\text { petal } \\
\text { shedding }\end{array}$ & $\begin{array}{c}7 \text {-14 days } \\
\text { after petal fall }\end{array}$ \\
\hline 'Hurdals' & $47.5 \mathrm{a}^{*}$ & $33.7 \mathrm{~b}$ & $50.0 \mathrm{a}$ & n.r. $^{* *}$ \\
'Maiden's Blush' & $55.0 \mathrm{a}$ & $32.5 \mathrm{~b}$ & $33.7 \mathrm{~b}$ & $12.5 \mathrm{c}$ \\
'Mousseuse Rouge & $67.5 \mathrm{a}$ & $66.3 \mathrm{a}$ & $53.8 \mathrm{a}$ & $63.8 \mathrm{a}$ \\
'Semiplena' & $67.5 \mathrm{a}$ & $68.7 \mathrm{a}$ & $72.5 \mathrm{a}$ & $41.3 \mathrm{~b}$ \\
\hline
\end{tabular}

"Note: The means with the same letters not differ significantly, according to Tukey's test $(\alpha=0.05$, one-way ANOVA).

${ }^{* *}$ N.r. - the cutting didn't root 
Table 6. The part of matrices of effect correlations between biologically active components before rooting and the percentage of rooted cuttings

\section{Variable}

\begin{tabular}{lc}
\cline { 2 - 2 } & 'Hurdals' \\
Poliphenolic acids & $0.749^{* * *}$ \\
Reducing carbohydrates in leaves & $-0.664^{* *}$ \\
Total carbohydrates in leaves & $-0.655^{* *}$ \\
Reducing carbohydrates in shoots & $-0.621^{* * *}$ \\
Total carbohydrates in shoots & -0.300 \\
Proteins & 0.290 \\
Chlorophyll $a$ & -0.073 \\
Chlorophyll $b$ & -0.088 \\
Carotenoids & -0.081 \\
SD & 25.76507 \\
Means [\%] & 36.25 \\
\hline Note: Marked correlations are significant at p $<0.05$. Correlation significance: ${ }^{*} 0.33$ \\
\\
phenological phases and their importance for rhizogenesis. \\
The suitable term to harvest the cutting on other species were the
\end{tabular}

The suitable term to harvest the cutting on other species were the aim of research of Torchik (2005) for Juniperus, Hossain et al. (2007) for Litchi, Funnel et al. (2003) for Limonium. The natural ability of roses to root formation can be used in methods of cultivation according to EU Council Directives (no. 91/414/EEC, 2009/128/WE, OJEU) and ecologically methods of cultivation. On the other side the ultimate goals of studying plant senescence are not only to understand process but, more importantly, to translate basic findings to senescencemanipulating technologies for agricultural improvement (Guo and Gan, 2014) on many fields. Zakizadeh et al. (2012) carried out researches according to exogenous ethylene resistance of pot roses.

The various period of blooming time characterize many of the once flowering roses (Monder, 2007; Monder, 2014). In this research, the content of the basic biologically active compounds (chlorophyll $a$ and $b$, carotenoids, total protein, carbohydrates in leaves and shoots, and polyphenolic acids) in following phenological phases were determining the condition of rooted cuttings four rose cultivars and was showed to change dynamically during the time of blooming, within 15-34 days ('Hurdals' 15 days, 'Maiden's Blush' 28 days, 'Mousseuse Rouge' 34 days, 'Semiplena' 22 days). Large variability confirmed the causes of the obtained differentiation of quality and quantity of the rooted cuttings. However, these relationships do not concern the cultivar which had a similar rooting percentage in cuttings from all four shoot phenological phases.

Husen (2008) proved, that the appropriate content of carbohydrates can be important for the success of the rhizogenesis process and they are released controllably. It is particularly important in case of plants which need a relatively long period to form adventitious roots (Denaxa et al, 2012; Hambrick et al., 1991). Additionally, it has been shown, that starch content was positively correlated to rooting of hardwood cuttings Rosa multiflora 'Brooks 56' (Hambrick et al., 1991). In research of Denaxa et al. (2012) the highest rooting percentage of olive 'Arbequinq' in summer coincided with the highest initial soluble sugars concentrations in cuttings, especially that of glucose and the lowest starch concentrations. The soluble sugars are more important than starch in rooting of olive (Denaxa et al., 2012). An increased content of carbohydrates in stock plants had a positive influence on the process of rhizogenesis only in the cuttings of 'Maiden's Blush', where both - sugar content and rooting percentage - fall with a successive phenological phase. However, in 'Hurdals' the cuttings of phase A1 rooted in a high percent, even though the lowest content of sugars before rooting Percentage of rooted cuttings

\begin{tabular}{lcc} 
iden's Blush' & 'Mousseuse Rouge' & 'Semiplena' \\
$0.467^{*}$ & -0.225 & -0.078 \\
0.171 & -0.107 & -0.256 \\
$0.456^{*}$ & -0.085 & -0.211 \\
$0.456^{*}$ & 0.022 & 0.001 \\
$0.373^{*}$ & -0.153 & -0.009 \\
0.210 & 0.099 & -0.246 \\
$-0.356^{*}$ & 0.127 & $-0.441^{*}$ \\
$-0.340^{*}$ & 0.107 & $-0.441^{*}$ \\
$-0.354^{*}$ & -0.144 & $-0.441^{*}$ \\
25.72075 & 18.33416 & 24.53584 \\
62.82 & 33.49 & 62.46 \\
\hline
\end{tabular}

0.499 - restrained; ${ }^{* *} 0.5-0.699$ - high; ${ }^{* * *}>0.7$ - very highly

was noted there in comparison to A2-A4, both in leaves and in shoots. For the two other cultivars the content of carbohydrates in the plant material before rooting did not matter. Therefore, it cannot be stated that a low rooting percentage for cuttings made from shoots 7-14 days after petal fall is due to a low carbohydrate level.

Trobec et al. (2005) examined an effect of phenol composition of rooting zones and root ability in the first days after the establishments of cuttings of cherry rootstock. They showed that the cuttings should contain certain levels of several phenolic compounds for starting of the root induction phase. In the case of 'Hurdals' roses (non rooted in A4) and 'Maiden's Blush' (the lowest rooting percentage in A4) it was evident that a higher content of polyphenolic acids increased the percentage of rooted cuttings. The levels of the polyphenolic acids in both these cultivars in A4 were the lowest among all the stages and this could have been the cause of a low rhizogenesis efficiency in cuttings harvested in this phenological phase.

In the present experiment in the stock plants an increase of the chlorophyll content in leaves in the consecutive A1-A4 phases was found for cultivars, in which the shoot maturity phase was decisive for a rooting percentage. Similar changes with each new phase of shoot maturity were observed in a warm climate plants - tea (Obanda and Okinda, 1995). Rose cuttings took root within ten weeks and during that time they were exposed to the course of aging natural in the vegetative season for moderate climate plants (Kraj, 2014). Moreover, the color change takes place during leaf senescence or accelerated cell death caused by various biotic and abiotic stress (Matile et al., 1999; Breeze et al., 2011). This phenomenon, accelerated, occurs also in cut flowers, resulting in a decrease in soluble protein (Rabiza-Świder et al., 2004) and chlorophyll $a$ and $b$ in leaves before their visible yellowing (Skutnik and Rabiza-Świder, 2004). The decreasing of chlorophyll and proteins is used as a biochemical marker of leaf senescence (Breeze et al., 2011; Kraj, 2014). A decrease in pigment content in leaves of stock plants of the studied roses in August, compared to the values in June, suggests a natural aging process advancing during the vegetative period and it was observed in 'Hurdals', 'Maiden's Blush' and 'Semiplena', while in 'Mousseuse Rouge' in August an increase in the studied averages occurred. In the latter cultivar differences in the percent of the rooted cuttings from A1-A4 shoots were not observed. In 'Hurdals' in turn, we suppose that this state of naturally early and fast ( 15 days) aging of leaves causes no rooting of A4 cuttings. This is confirmed by the fact that after rooting in the leaves of this cultivar chlorophyll content decreased in relation to the level in stock plants in June, and the protein content - also in relation 
98

to the level in August. An advancing aging process in the rooted cuttings of consecutive phases was also observed in 'Semiplena' and 'Maiden's Blush', where A4 cuttings rooted in the smallest percentage. The present study leads to a conclusion that the process of aging in rose leaves starts earlier e.g. in comparison to Fagus sylvatica, where the chlorophyll content of the leaves was stable until the first days of September (Kraj, 2014). The similar changes in pigments content were observed in research on Rosa gallica 'Duchesse d'Angoulême', but the most striking effects were in rooted cuttings derived from shoots collected just after flower petal fall comparing with other term (Monder et al., 2014). Our study confirms the big significance of stock plant leaves in the process of rooting (Costa, 2002).

\section{Conclusions}

The seasonal changes in plant tissues are natural process. A choice of a right shoot developmental phase of rose cultivars under study has a decisive effect for a success of their propagation. Cuttings of each cultivar made from shoots with flower buds closed rooted in a high percentage while those from shoots 7-14 days after petal fall had the lowest rooting percentage ('Maiden's Blush', 'Semiplena') or did not root at all ('Hurdals'). Only the cuttings of 'Mousseuse Rouge' rooted similarly, regardless of a phenological phase of the stock plant.

The contents of the biologically active compounds studied in his trial varied in the cultivars. During rooting the pigment (chlorophyll $a$ and $b$, carotenoids) levels decreased what might have been due both to senescence in cuttings' leaves and the natural end of the vegetative season. Cuttings of 'Maiden's Blush' and 'Semiplena' rooted in a higher percent in spite of a lower content of chlorophyll $a$ and $b$ and carotenoids. In 'Hurdals' and 'Maiden's Blush' an increased content of polyphenolic acids had a positive influence on the rooting percentage. A reason for a low efficiency of rhizogenesis in cuttings of 'Maiden's Blush' and 'Hurdals' made from shoots 7-14 days after petal fall might have been a low level of polyphenolic acids in stock material, determined before rooting.

A relationship between changes in the biologically active compounds in the successive developmental phases of roses and rooting of their cuttings as well as an effect of other changes occurring during rooting on rhizogenesis need further studies.

\section{Acknowledgments}

This work was supported by National Science Centre 2011-2014 [the research project no. NN 310008240].

\section{References}

Arnon DI (1949). Copper enzyme in isolated chloroplasts. Polyphenoloxidase in Beta vulgaris. Plant Physiology 4:1-15.

Blythe EK, Sibley JL, Ken M, Tilt KM, RuterJM (2007). Methods of auxin application in cutting propagation: a review of 70 years of scientific discovery and commercial practice. Journal of Environmental Horticulture 25(3):166-185.

Breeze E, Harrison E, McHattie S, Hughes L, Hickman R, Hill C, ... Wollaston VB (2011). High-resolution temporal profiling of transcripts during Arabidopsis leaf senescence reveals a distinct chronology of processes and regulation. The Plant Cell 23:873-894.
Costa JM (2002). The role of the leaf in growth dynamics and rooting of leafy stem cuttings of rose. $\mathrm{PhD}$ thesis. Wageningen University, The Netherlands.

CostaJM, Challa $\mathrm{H}$ (2002). The effect of the original leaf area on growth of soffwood cuttings and planting material of rose. Scientia Horticulture 95(1):111-121.

Costa JM, Heuvelink E, Pol PA, Put HMC (2007). Anatomy and morphology of rooting in leafy rose stem cuttings and starch dynamics following severance. Acta Horticulturae 751:495-502.

Denaxa N-K, Vemmos SN, Roussos PA (2012). The role of endogenous carbohydrates and seasonal variation in rooting ability of cuttings of an easy and a hard to root olive cultivars (Olea europaea L). Scientia Horticulture 143:19-28.

Dubois M, Gilles KA, Hamilton JK, Rebers PA, Smith F (1956). Colorimetric method for determination of sugars and related substances. Analytical Chemistry 28(3):350-356.

FuZ, Xu P, HeS, Teixeira da SilvaJA, Tanaka M (2011). Dynamic changes in enzyme activities and phenolic content during in vitro rooting of tree peony (Paeonia suffruticosa Andr.) plantlets. International Journal of Sciences and Technology 5:252-265.

Funnel KA, Bendall M, Fountain WF, Morgan ER (2003). Maturity and type of cutting influences flower yield, flowering time, and quality in Limonium 'Chorus Magenta'. New Zealand Journal Crop Horticultural Science 31:139-146.

Ghosh S, Gepstein S, Heikkila JJ, Dumbroff EB (1988). Use of scanning densitometer or an ELISA Plate Reader for measurement of nanogram amounts of protein in crude extracts from biological tissues. Analytical Biochemistry 169:227-233.

Ginova A, Tsvetkov I, Kondakova V (2012). Rosa damascena - an overview for evaluation of propagation methods. Bulgarian Journal of Agricultural Science 18(4):514556.

Gitelson A, Merzlyak MN (1994). Spectral reflectance changes associated with autumn senescence of Aesculus hippocastanum L. and Acer platanoides L. leaves. Spectral features and relation to chlorophyll estimation. Journal of Plant Physiology 143:286-292.

Guo Y, Gan S-S (2014). Translational researches on leaf senescence for enhancing plant productivity and quality. Journal of Experimental Botany 65:3901-3913.

Gustavsson LA (1999). Rosen Leksikon, [Roses encyclopedia]. Rosinante ForlagA/SCopenhagen.

Hambrick CE, Davies FT, Pemberton HB (1991). Seasonal changes in carbohydrate / nitrogen levels during field rooting of Rosa multiflora 'Brooks 56 hardwood cuttings. Scientia Horticulture 46:137-146.

Hossain D, Choudhury MSH, Hasan M, Yeasmin R, Islam A (2007). Effect of maturity and time of operation on litchi air layering. Journal of Agroforestry and Environment 1(2):147-148.

Husen A (2008). Stock-plant etiolation causes drifts in total soluble sugars and anthraquinones, and promotes adventitious root formation in teak (Tectona grandis L.) coppice shoots. Plant Growth Regulation 54(1):1321.

Hwnag CH, Sim DJ, ParkJE, ParkJE, Park YG,Jeong BR (2015). Location in canopy of the stock plant affects rooting and subsequent growth in cutting propagation roses. Propagation of Ornamental Plants 15(4):136-141. 
Lim PO, Kim HJ, Nam HG (2007). Leaf senescence. Annual Review of Plant Biology 58:115-136.

Kraj W (2014). Proteolytic activity and nitrogen remobilisation in senescing leaves on phenological forms of Fagus sylvatica. Dendrobiology 72:163176.

Matile P, Hörtensteiner S, Thomas H (1999). Chlorophyll degradation. Annual Review Plant Physiology and Plant Molecular Biology 50:6795.

Monder MJ (2007). Zasoby genowe i ocena wybranych odmian róż historycznych w kolekcji Ogrodu Botanicznego CZRB PAN, [Genetic resources and evaluation of selected historical roses]. Zeszyty Problemowe Postępów Nauk Rolniczych 517(II):487494.

Monder MJ (2014). Evaluation of growth and flowering of historical cultivars of Rosa gallica L. growing in the National Collection of Rose Cultivars in the Polish Academy of Science Botanical Garden in Powsin. Acta Agrobotanica 67(3):39-52.

Monder MJ, Niedzielski M, Woliński K (2014). Effect of rooting preparations on protein, chlorophyll and carotenoid content in leaves of Rosa gallica 'Duchesse d'Angoulême' cuttings. Dendrobiology 72:2939.

Moroz EK (2006). Korniesoobstwiennyje rozy w Nacionalnom Parkie 'Sofiewka', [Roses on own roots in National Park 'Sofiewka']. NANU CentralnyjBotaniczeskijSad, Umań.

Nasri F, Fadakar A, Saba MK, Yousefi B (2015). Study of indole butyric acid (IBA) effects on cutting rooting improving some of wild genotypes of damask roses (Rosa damascena Mill.). Journal of Agricultural Sciences 60(3):263-275.

Nelson A (1944). A photometric adaptation of the Somogyi method for determining glucose. Journal of Biological Chemistry 153:375-380.

Obanda M, Okinda P (1995). Impact of shoot maturity on chlorophyll content, composition of volatile flavour compounds and plain black tea chemical quality parameters of clonal leaf. Journal of the Science Food and Agriculture 69(4):529-534.

Okoro OO, Grace J (1976). The physiology of rooting Populus cuttings. I. Carbohydrates and photosynthesis. Physiologia Plantarum 36:133-138.

Pihlajaniemi H, Siurainen M, Rautio P, Laine K, Peteri SL, Huttunen S (2005). Field evaluation of phenology and success of hardy, micropropagated old shrub roses in northern Finland. Acta Agriculturae ScandinavicaSection B-Soil and Plant Science 55(4): 275-286.

Pietrakowski D (2006). Wpływ dolistnego stosowania auksyn na ukorzenianie sadzonek różz grupy okrywowych, [The influence of foliar application of auxin on rooting cuttings of ground cover roses]. $\mathrm{PhD}$ Thesis, Poznań University of Life Sciences, Poznań.
PTF (1999) Polskie Towarzystwo Farmakologiczne - Farmakopea Polska [Polish Pharmacological Society - Polish Pharmacopoeia V]. Polskie Towarzystwo Farmakologiczne, Warsaw 5:445-446.

Rabiza-Świder J, Skutnik E, Wachowicz M, Łukaszewska A (2004). Senescence of cut leaves of Zantedeschia aethiopica and Z. elliottiana. Part II. Free amino acids accumulation in relation to soluble protein content. ActaScientiarum Polonorum Hortorum Cultus 3(2):67-74.

Rosenverzeichnis Rosarium Sangerhausen (1988). 3 Auflage, Sangerhausen, Germany.

Skutnik E, Rabiza-Świder J (2004). Longevity of cut shoots of Molucella laevis $\mathrm{L}$. as affected by flower preservatives and growth regulators. Folia Horticulturae 16:167-173.

Smart CM (1994). Gene expression duringleaf senescence. New Phytologist 126(3):419-448.

Strzelecka H, Kamińska M, Kowalski J (1982). Chemiczne metody badań roślinnych surowców leczniczych [Chemical methods of analysis medicinal plants]. Państwowy Zakład Wydawnictw Lekarskich, Warszawa.

Torchik V (2005). Effect of donor plant phenological phase on root formation of stem cuttings of ornamental Juniperus L. cultivars. Propagation of Ornamental Plants 5:51-55.

Trobec M, Stampar F, Veberic R, Osterc G (2005). Fluctuations of different endogenous phenolic compounds and cinnamic acid in the first days of the rooting process of cherry rootstock 'Gisela 5 ' leafy cuttings. Journal of Plant Physiology 162(5):589-97.

Watanabe M, Balazadeh S, Tohge T, Erban A, Giavalisco P, Kopka J, Mueller-Roeber B, Fernie A, Hoefgen R (2013). Comprehensive dissection of spatiotemporal metabolic shifts in primary, secondary, and lipid metabolism during developmental senescence in Arabidopsis. Plant Physiology 162:1290-1310.

Wiśniewska-Grzeszkiewicz H, Podwyszyńska M (2001). Propagation of ground cover roses by stem cuttings and tissue culture. Acta Horticulturae 547:371-376.

Woo HR, Kim HJ, Nam HG, Lim PO (2013). Plant leaf senescence and death - regulation by multiple layers of control and implications for agingin general. Journal ofCell Science 126(21):4823-4833..

Wójcik AR, Laudański Z (1989). Planowanie i wnioskowanie statystyczne $\mathrm{w}$ doświadczalnictwie, [Statistical planning and concluding in experimental works]. Państwowe Wydawnictwo Naukowe, Warsaw, Poland.

Zakizadeh H, Lutken H, Sriskandarajah S, Serek M, Muller R (2013). Transformation of miniature potted rose (Rosa hybrida) cr. Linda with $\mathrm{P}(\mathrm{SAG} 12)$-ipt gene delays leaf senescence and enhances resistance to exogenous ethylene. Plant Cell Reports32:195-205. 